\title{
Development of a Framework Regarding the Factors Affecting Academics in Higher Education's Turnover Intentions
}

\author{
Sujit Kumar Basak \\ Department of Information Technology, Durban University of Technology, South Africa \\ Email: sujitbasakmca@gmail.com
}

\section{Doi:10.5901/mjss.2014.v5n23p421}

\section{Abstract}

This paper presents a framework regarding the factors affecting university academic turnover intentions in higher education, derived from an in-depth survey of the related literature. The aim of this study was achieved by identifying factors that affect university academic turnover intentions. The main result of this study is the design a framework, derived from existing literature, of factors affecting university academics' turnover intentions. The findings help to articulate issues related to university acadmeics' turnover intentions and in this way contribute to the development of the programs that designed to address the relevant issues.

Keywords: university; turnover intentions; academics; factors;

\section{Introduction}

Turnover is very important concept to any organizations and individuals. According to Kim et al. (1996) turnover is the voluntary or involuntary permanent withdrawal to any organization. It refers to an individual's probability where an employee will leave an organization in the near future (Tert and Meyer, 1993). In higher education, employee turnover is higher as human resources with the knowledge and with the competences because these two are the key assets which affects academic and research activities in the organization. The turnover affect very highly because it is very difficult for university to organize substitute new faculty in the middle of the course (Ongori, 2007). Zhou and Volkwein (2004) states that the cost of academic staff turnover includes subsequent recruit expenses, disruptions of the course offerings, discontinuities in the departmental and student planning, and loss of the student graduate advisors, etc. Ahmad and Riaz (2001) argued that high turnover among full-time academic staff basically undermine the institutional goals of providing incentives for the quality education and the intellectual creativity. According to Smart (1990), three sets of determinants that explains turnover intentions for university academics which includes individual characteristics reflects demographic and work factors, and contextual variables reflects individual stature and adjustment of the work environment and finally multiple dimensions of organizational and career satisfaction.

\section{Problem Statement}

According to Ali (2008), in Pakistan, on average the lecturer's turnover is more than 60\%. Pienaar and Bester (2008) stated that academic turnover intentions have got several disadvantages which includes cost related to decrease the organizational loyalty, loss of knowledge and the experience with regards to the institution, and increase the time and cost in the training novice academic. Sanderson et al. (2000) reported that from 1997 to 1998 in U. S. 7.7\% of academic staff left their institutions, of these 29 percent were retirees and the remaining $71 \%$ left their jobs for various reasons. They also reported from the 2000 academic staff and concluded that $40 \%$ of them are considering to leave their careers (Sanderson et al., 2000), in the case of Australia, the higher education $68 \%$ of academic staff wish to leave the higher education (Sanderson et al., 2000). Tettey (2006) argued that South African higher education institutions academics leave between $5 \%$ and $18 \%$ of their jobs. Similarly, Barnard and Rodgers (1998) also reported in Singapore, South Africa, and Taiwan the leaving rates are $3.4 \%, 2.9 \%$, and $2.7 \%$.

Cartter (1976) indicated doctorate degree holders are changing their affiliation on an annual basis which declined from $8 \%$ (mid of 1960) to $1.4 \%$ (in the year 1972). On the other hand, Finkelstein (1984) indicated from the National Science Foundation, the decline rate from 3.5\% professors are leaving their jobs in mid-1960s to about $1 \%$ in the late 
1970s. A report by the World Bank indicated "Retaining Teaching Capacity in African Universities (1995), it was estimated that approximate 23,000 African qualified academic staff are emigrating each year for the better working conditions".

\section{Research Question}

What are the important factors that affect university academics turnover intentions?

\section{Aims and Objectives}

The aim of this study is to develop a conceptual framework regarding the factors affecting university academics turn over intentions. The aim was achieve through accomplishing the following objectives: identify the factors affecting university academics turnover intentions; examine the action and strategies that university academics should take in order to decrease the turnover intentions.

\section{Literature Review}

A study was conducted by Nwadiani and Akpotu (2002) in Nigeria, using a questionnaire based survey on eight universities, 442 academic staff and 44 former academic staff. Their research results shows the average turnover rate is $16.18 \%$ and the total 1,476 lecturers left their university job permanently. Their study also indicated that professor got $20.88 \%$ turnover rate which considered the highest turnover rate, followed by social sciences lecturers' got $20.58 \%$ and female got 18.99\% turnover rate. Kipkebut (2010) conducted a study in Kenyan universities and found employees' turnover intentions includes role conflict, promotional opportunities, and age is some of the many factors which cause university academic to leave. In Kenya, another study was conducted by Ng'ethe et al. (2012) using a questionnaire based survey on 547 academic staff members from the seven public universities and their results shows leadership style inversely and significantly influence on academic staff to leave the organization.

Study conducted by McGee and Ford (1987) found faculty members' teaching responsibilities negatively affect academic turnover intentions. A research results from Johnsrud and Rosser (2002) indicated demographic variables, perceptions of faculty worklife such as professional workload, administrative relations and support, etc. and interrelated dimensions of morale such as engagement of work, institutional regard etc. subsequently influence academics to leave their job, institution, and career. A study conducted using a questionnaire based survey by Zahra et al. (2013) on academics and their results shows that remuneration, supervisory support and the work life have influence for academics in terms of turn over intentions.

A survey was conducted by Conklin and Desselle (2007) on Pharmacy faculty members and their questionnaires were sent via e-mails and the analysis from their results shows that 5 reasons which influence academics turnover intentions such as excessive workload, seeking a new challenge, poor salary, and poor relationships with college or school administrators. Study by Al-Omari et al. (2008) on 150 faculty members in 2007/2008 term and their results shows structural, psychological, and environmental variables influence directly and indirectly turnover intentions. Weiler (1985) and Matier (1990) conducted studies and reported salary has a significant factor that influence academics turnover intentions.

\section{Methodology}

The strategy introduced in this paper was to identify the main factors that affect university academics turnover intensions. The identification was drawn from existing literature and the results of this paper were drawn by compiling turnover intentions factors affecting by university academics. A systematic literature review based on the following steps: formulate the review question, devising the search strategy, application of the study selection criteria, study design, and the quality appraisal (Croucher et al., 2003).

\subsection{The Review Question}

The formulation of the question was identified by a systematic review and the question provides the focus and boundaries, shapes all aspect of review process: inclusion and exclusion criteria, the search strategy, amount of literature reviewed, the quality appraisal, and the synthesis of evidence (Wallace et al., 2005). The review question was guided by the following question: what are the factors affecting university academics turnover intentions? 


\subsection{The Search Strategy}

Google, Google Scholar and the University library electronic databases were searched utilizing the search terms such as: "factors affecting university academics turnover intentions,"; "turnover intentions by university academics,"

\subsection{Application of Study Selection Criteria}

Before studies entered into systematic review, they were subjected to the two filters such as first filter and the second filter. The first filter - comprissed a set of inclusion and exclusion criteria so that only relevant and able to address review question is taken through to the second filter (Wallace et al., 2005).

\subsection{Design of the Studies}

Studies included empirical evidence from the experimental or observational research which include qualitative research. The study also includes unpublished or published work (Wallace et al., 2005). In this article, only selected those are directly associated with factors affecting university academics turnover intentions.

\subsection{The Quality Appraisal Criteria}

Studies included met all the five necessity elements of the quality appraisal criteria (Wallace et al., 2005, source: Croucher et al., 2003) for validity and trustworthy findings. Articles were selected which were strongly considerable, acceptable, reliable and the empirically valid. Furthermore, studies considered to each study had the good research questions and theory, model or theoretical framework.

\section{Results}

The results of this study are displayed in Figure 1.

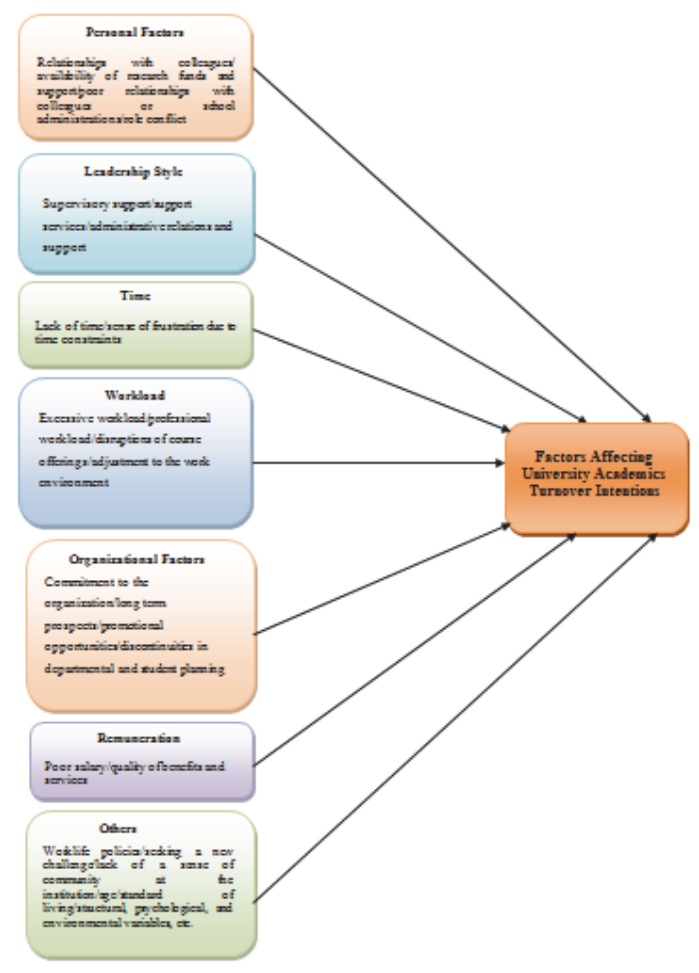

Figure 1. A Proposed Framework Regarding Factors Affecting University Academics' Turnover Intentions 


\section{Disscussion, Conclusion and Recommendations}

The main objective of the study was to examine the factors affecting university acadmeics turnover intentions. This study has revealed all the major factors that affect university academics turnover intentions. According to Vroom (1964), the expectancy theory includes structural, psychological, and environmental variables. However, regardless of what theory is applied issues such as the personal factors, remuneration, time, leadership style, workload, organizational factors, and others (worklife, policies, seeking a new challenge, lack of a sense of community at the institution, age, standard of living, etc.) to be factors that affect university academics turnover intentions.

This study however, recommends that university academics should endeavour to know what factors that affects them to turnover. Furthermore, this study will also help university acadmics to know which factors are likely to affect their turnover intentions.

\section{References}

Ahmad, T. and Riaz, A. (2011). Factors affecting turn-over intentions of doctors in public sector medical colleges and hospitals. Interdisciplinary Journal of Research in Business, 1(10), 57-66, 2011.

Ali, N. (2008). Factors affecting overall job satisfaction and turnover intentions. Journal of Managerial Sciences, 2(2), 240.

Al-Omari, A. A. Qablan, A. M. and Khasawneh, S. M. (2008). Faculty members' intentions to stay in Jordanian public universities, IJAES, $1(1)$.

Barnard, M. E. and Rodgers, R. A. (1998). What's in the package? Policies for the internal cultivation of human resources and for high performance operations, Asia Academy of Management (Hong Kong).

Cartter, A. M. (1976). Ph.Ds and the Academic Lobor Market. New York: McGraw-Hill.

Conklin, M. H. and Desselle, P. S. (2007). Job turnover intentions among pharmacy faculty, American Journal of Pharmaceutical Education, 71(4).

Croucher, K. Quilgars, D. Wallace, A. Baldwin, S. and Mather, L. (2003). Paying the Portage. A Systematic Literature Review of Safety Nets for Home Owners, York: Department of Social Policy and Social Work.

Finkelstein, M. J. (1984). The American Academic Profession. Columbus, OH: Ohio State University Press.

Johnsrud, L. K. and Rosser, V. J. (2002). Faculty members' morale and their intentions to leave: A multilevel explanation, The Journal of Higher Education, 71(1), 34-59.

Kipkebut, D. J. (2010). Organisational Commitment and Job Satisfaction in Higher Educational Institutions: The Kenyan Case. PhD thesis, Middlesex University.

Kirn, S. Price, J. Mueller, C. and Watson, T. (1996). The determinants of career intent among physicians at a US Air Force hospital, Human Relations, 49(7), 947-976.

Matier, M. W. (1990). Retaining faculty: a tale of two campuses, Research in Higher Education, 31(1), 39-60.

McGee, G. W. and Ford, R. C. (1987). Faculty research productivity and intentions to change position, Review of Higher Education, 11(1), 1-16.

Ng'ethe, J. M. Namusonge, G. S. and Iravo, M. A. (2012). Influence of leadership style on academic staff retention in public universities in Kenya, International Journal of Business and Social Science, 3(21).

Nwadiani, M. and Akpotu, N. E. (2002). Academic staff turnover in Nigerian universities (1990-1997), Education, 123(2), 305-312.

Ongori, H. (2007). Review of the literature on employee turnover, African Journal of Business Management, 49-54.

Pienaar, C. and Bester, C. L. (2008). Retention of academics in the early career phase, SA Journal of Human Resource Management, 6(2), 32-41.

Sanderson, A. Phua, V. and Herda, D. (2000). The American Faculty poll. TIAA- CREF, New York: National Opinion Research Center, Illinois: Chicago.

Smart, J. C. (1990). A causal model of faculty turnover intentions, Research in Higher Education, 31(5), 405-424.

Tert, R. and Meyer, J. (1993). Job satisfaction, organizational commitment, turnover intentions, and turnover: Path analyses based on meta-analytic findings, Personnel Psychology, 46(2), 259-294.

Tettey, J. W. (2006). Staff Retention in African Universities: Elements of a Sustainable Strategy, Washington, DC: World Bank.

Vroom, V. H. (1964). Work and Motivation. San Francisco, CA: Jossey-Bass.

Wallace, A. Bevan, M. Croucher, K. Jackson, K. O'Malley, L. and V. Orton, V. (2005). The Impact of Empty, Second and Holiday Homes on the sustainability of Rural Communites-a Systematic Literature Review, The centre for housing policy, The University of York, 1-142.

Weiler, W. C. (1985). Why do faculty members leave the university?, Research in Higher Education, 23(3), 270-277.

Zahra, S. Irum, A. Mir, S. Chishti, A. (2013). Job satisfaction and faculty turnover intentions: a case of Pakistani Universities, IOSR Journal of Business and Management (IOSR-JBM), 9(2), 83-89.

Zhou, Y. and Volkwein, J. (2004). Examining the influences on Faculty Departure Intentions: A Comparison of Tenured Versus Nontenured Faculty at Research Universities, Research in Higher Education, 45(2), 139-176. 